\title{
Challenges in Establishing the Professional Ergonomist Certification Scheme in Malaysia
}

\author{
Shamsul Bahri Mohd Tamrin'(shamsul_bahri@upm.edu.my), Muhammad Syafiq Syed \\ Mohamed $^{2}$ (syafiq@utem.edu.my) and Ng Yee Guan'(shah86zam@upm.edu.my) \\ ${ }^{1}$ Department of Environmental and Occupational Health, Faculty of Medicine and Health Sciences, Universiti \\ Putra Malaysia \\ ${ }^{2}$ Faculty of Manufacturing Engineering, Universiti Teknikal Malaysia Melaka \\ ${ }^{1,2}$ Human Factors and Ergonomics Society Malaysia
}

\begin{abstract}
The certified professional ergonomist scheme is a requirement for any country that wishes to recognize the field of ergonomics as a professional service rendered by qualified and competent persons for the benefit of the public. Various countries like USA, Europe, Australia and New Zealand have already established the professional ergonomist scheme in their countries. However the recognition for the need to have a professional ergonomist certification scheme is slowly being brought forth in developing countries such as Malaysia, where the field of ergonomics is relatively unknown to the Malaysian public. However, since the field of ergonomics have become more popular in Malaysia, the need to have a Malaysian professional ergonomist certification scheme became quite important. Developing a professional ergonomist certification scheme in Malaysia is not without any challenges. Some of the notable challenges are the absence of any clearly stated standards or regulation within legal framework which requires ergonomics competency, establishing educational standards which are culturally relevant to Malaysia, establishing the route of certification which suites Malaysia context due to diversity of experience, exposure to ergonomics intervention and other programs and operational challenges in setting up Malaysian ergonomist certification framework. All these challenges are described in this paper.
\end{abstract}

Keywords: CPE, Malaysia, professional ergonomist, DOSH, ergonomics, challenge

\section{Introduction}

As a rapidly developing country, Malaysia has seen a rapid industrial growth since the early 1970's until early 2000's. Many multinational companies have set up their production bases in Malaysia such as FreeScale (formerly known as Motorola), Intel, Agilent, Dell and many other companies as well. Affordable labor cost, stable political climate, and excellent road and transportation system have made Malaysia very attractive for foreign investments. Along with the rapid growth of industrialization, the concern for safety and health of the workers also began to rise, especially cases involving work related musculoskeletal disorders among workers. It is with this concern that many companies in Malaysia are paying close attention to ergonomics in the workplace, and this is especially true for multinational companies in Malaysia. However, the awareness on ergonomics among general public in Malaysia is still at a low level as this can be clearly seen based on the statistics related by the Department of Occupational Safety and Health (DOSH) on the arising numbers of ergonomics related diseases and by The Department of Social Security with the increasing numbers compensated cases of musculoskeletal disorders.

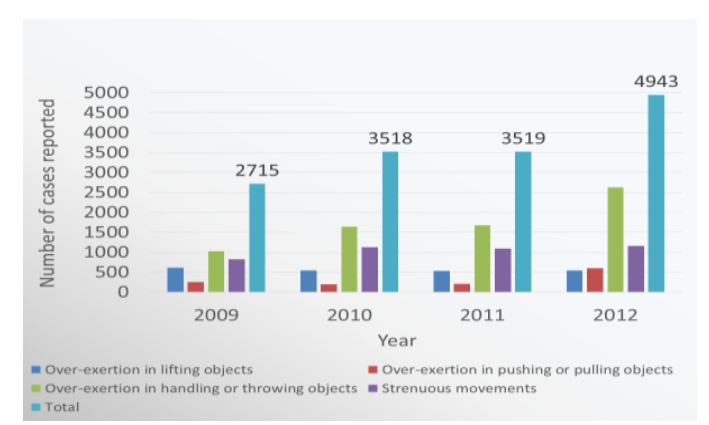

Figure 1: Numbers of cases reported related to ergonomics risks 
Although indirect, the legislation related to several parts of ergonomics had been established since the introduction of the Factory and Machinery Act (1967). Several sections within the Factory and Machinery Act relates to environmental ergonomics especially in Safety and Health Welfare Regulation that emphasized on heat stress, ventilation and manual handling. However, in 1989, a specific regulation on noise exposure was introduced within the Act indicating the importance of hearing loss due to environmental ergonomics. The step by step inclusion of ergonomics aspects in the Malaysian legal act indicates that Malaysian authorities are slowly realizing the importance of ergonomics in the Malaysian workplace.

The introduction of Occupational Safety and Health Act (1994), marked the new beginning of Ergonomics in Malaysia. Although there is no specific regulation within the Act, one of the objectives stipulated in the Act is to ensure that work environment adapt to the worker physiological and psychological need. Based on the objective of the Act, the Department of Occupational Safety and Health had published several guidelines including

- Guidelines on Occupational Vibration (2003)

- Guidelines on Occupational Safety and Health for Working with Video Display Units (VDU)

- Guidelines on Occupational Safety and Health for Seating at Work

- Guidelines on Occupational Safety and Health for Standing at Work

In addition to Malaysian Legislations, a total of 105 ergonomics technical standards were developed based on ISO standards. Although after 23 years after the introduction of OSH Act 1994, the awareness of ergonomics in Malaysia is still unsatisfactory. A survey conducted by Human Factors and Ergonomics Society Malaysia in 2013 among $400 \mathrm{OSH}$ personnel had shown that $87 \%$ of them were not aware of any ergonomics guidelines either by DOSH or international standards, however more than $67 \%$ claimed of having knowledge of ergonomics. In addition, DOSH (2012), reported that their total inspection to industries was only 500 inspection yearly compared to other industrial hygiene inspection.

To cater the issue of low awareness among companies, DOSH had promoted a two year initiative under the new OSH Master Plan 2020, a systematic occupational health's program (SoHelp) in promoting ergonomics and industrial hygiene among companies in Malaysia. The program with its 5 level of implementation is to ensure that industries have commitment from their management in promoting ergonomics, conduct risk assessment and implementation of ergonomics improvement based on the recommendations of the risk assessment.

As a continuation of this initiative by the government of Malaysia, DOSH and HFEM had developed an upgraded risk assessment method based on the checklist used in SoHelp program. The guideline of ergonomics risk assessment at the workplace 2017 requires ergonomics risk assessment to be conducted by a trained person in ergonomics risk assessment. The requirement of a trained person in ergonomics is a major breakthrough in promoting the establishment of a certified professional ergonomics in Malaysia as there is a plan by the Ministry of Human Resource (MOHR), in endorsing an ergonomics assessor within the new amendment of OSH Act. The establishment of ergonomics assessor will be the first time within the legal requirements of safety and health in Malaysia.

Although there are initiatives by the government of Malaysia in promoting ergonomics, there are various challenges in establishing a certified professional ergonomist certification scheme.

\section{Challenges}

\subsection{Absence of any clearly stated standard or regulation within legal framework which requires Ergonomics competency}

Currently in Malaysia there has yet to be a specific legal requirement concerning the implementation of ergonomics in the workplace. Currently it is only covered in a very general, loosely defined term under Section 12 of the Malaysia FMA 1967 Act, which stated that "No person shall be employed to lift, carry or move any load so heavy as to be likely to cause bodily injury to him." This is a very general statement concerning ergonomics in the workplace. As workers are more likely to suffer from low back pain while working in Malaysian industries, which are primarily labor intensive. With such a loosely defined legal term, employers often do not pay much attention towards that particular section in the FMA 1967 Act. Therefore, the safety enforcement officers in Malaysia also have difficulties in defining exactly what is meant by the term ".......any load so heavy...." since it is very vague. Unlike certain chemicals which have exposure limits clearly stated in the law, for ergonomics it is very hard to link the exposure towards ergonomic risk factors and the occurrence of musculoskeletal disorders. 


\subsection{Establishing educational standards which are culturally relevant to Malaysia}

With the current awareness of ergonomics remained low among OSH personnel and community remained low, the demand for secondary school and universities to produce modules and program related to ergonomics discipline remain a non-priority. Although topics or modules in physical, cognitive ergonomics or HCI (human computer interaction) including Interaction Design, Usability Engineering, User Centered Design, User Interface Design, Human Centered Technology, Ergonomics Design, Automotive Ergonomics, Industrial Ergonomics, Cognitive Ergonomics, Space Planning \& Ergonomics had been implemented by several universities and colleges, it remained a loose form for an elective courses within undergraduate program in industrial engineering, safety and health or psychologist. There was an attempt by a private college to introduce a diploma program in ergonomics but the initiative was a failure as no long terms framework in educating the industry to hire ergonomics within their organization.

The Malaysian public must be taught the importance of ergonomics in their daily lives and in their workplaces so the practice of ergonomics can be appreciated by all. The importance of having ergonomics to be recognized as a professional discipline needs to be understood by the Malaysian public as well as relevant authoritative agencies in Malaysia. This is the reason why we have included senior officials from the Department of Occupational Safety and Health Malaysia as well as the National Institute of Occupational Safety and Health Malaysia (NIOSH) to be part of the committee for establishing the professional ergonomist certification scheme in Malaysia. With the support from the relevant authoritative bodies in Malaysia, the public will slowly recognize ergonomics as a professional discipline in Malaysia.

As ergonomics is not taught in most of the universities and colleges in Malaysia, it is very difficult for the committee to demand specific knowledge areas in ergonomics such as the ones outlined by various international ergonomics societies around the world. Taken example the European ergonomist requirement; candidates had to fulfill certain credit hours in specific areas of ergonomics including physiological and physical aspects, psychological and cognitive aspects as well as social and organizational aspects of ergonomics. This is equivalent within the requirements outlined by the International Ergonomics Association (IEA) as they prefer applicants to have a first level university qualification in ergonomics of a minimum of three years duration. Table 1 shows examples of minimum requirements set by several countries. Therefore, there is a need to improve the basic curriculum structure beginning with secondary school or poly technique colleges where module related to ergonomics to be incorporated and for tertiary education, modules to ergonomics to be recognized as minor in ergonomics or to the extends of developing a new undergraduate or post graduate program in ergonomics.

Table 1: Minimum Requirements of other IEA endorsed certification bodies 


\begin{tabular}{|c|c|c|c|c|}
\hline Country & Designation & Theory /Education & Practice & Further requirem. \\
\hline Australia & $\begin{array}{l}\text { Certified } \\
\text { Professional } \\
\text { Ergonomist }\end{array}$ & $\begin{array}{l}\geq 3 \text { yrs. Undergraduate degree in } \\
\text { Ergonomics } \\
\qquad \text { OR } \\
\text { Postgraduate Diploma or Coursework } \\
\text { Masters in Ergonomics } \\
\quad \text { OR } \\
\geq 4 \text { yrs University level qualification } \\
\text { in a related field incl. major } \\
\text { component in Ergonomics }\end{array}$ & $\begin{array}{l}\text { Expertise demonstrated } \\
\text { by } 1 \text { major and } 1 \text { minor } \\
\text { work sample } \\
\quad \text { AND } \\
\geq 4 \text { yrs. Full time } \\
\text { practice }\end{array}$ & $\begin{array}{l}\text { Active } \\
\text { Membership in } \\
\text { Ergonomics } \\
\text { Society for } \geq 2 \text { yrs. }\end{array}$ \\
\hline \multirow[t]{3}{*}{$\begin{array}{l}\text { Canada } \\
(\mathrm{CCPE})\end{array}$} & $\begin{array}{l}\text { Canadian } \\
\text { Certifed } \\
\text { Professional } \\
\text { Ergonomist }\end{array}$ & $\begin{array}{l}\text { Ergonomics Courses (curriculum } 700 \\
\text { hrs }+8 \text { weeks field work) }\end{array}$ & $\begin{array}{l}\geq 4 \text { yrs experience incl. } 1 \\
\text { mentored year OR } \\
\geq 5 \text { yrs experience }\end{array}$ & \\
\hline & $\begin{array}{l}\text { Ditto } \\
\text { (mature) }\end{array}$ & & $\geq 10$ yrs of experience & \\
\hline & $\begin{array}{l}\text { Associate } \\
\text { Ergonomist }\end{array}$ & \multicolumn{3}{|c|}{ same as CCPE, but awarded if practical experience requirements are not yet met. } \\
\hline $\begin{array}{l}\text { Europe } \\
\text { (CREE) }\end{array}$ & $\begin{array}{l}\text { European } \\
\text { Ergonomist }\end{array}$ & $\begin{array}{l}\geq 1 \text { yrs devoted to ergonomics courses } \\
\text { (curriculum } 660 \mathrm{hrs} \text { ) }\end{array}$ & $\begin{array}{l}\geq 1 \text { yrs of supervised } \\
\text { training or examined } \\
\text { project work } \\
\quad \text { AND } \\
\geq 2 \text { yrs of unsupervised } \\
\text { professional experience }\end{array}$ & $\begin{array}{l}\text { Total time of } \\
\text { training } \\
\text { expected } \geq 6 \text { yrs of } \\
\text { which min } \geq 4 y r s \\
\text { dedicated to } \\
\text { ergonomics }\end{array}$ \\
\hline \multirow[t]{3}{*}{ Japan (JES) } & $\begin{array}{l}\text { Ergonomics } \\
\text { practitioner } \\
\text { (option } 1 \text { ) }\end{array}$ & $\begin{array}{l}3 \text { yrs. Professional ergonomics } \\
\text { training at College or graduate school }\end{array}$ & $\geq 2$ yrs job practice & $\begin{array}{l}\text { written exam }+ \\
\text { interview }\end{array}$ \\
\hline & $\begin{array}{l}\text { Ergonomics } \\
\text { practitioner } \\
\text { (option } 2)\end{array}$ & Any college degree & $\geq 7$ yrs job practice & $\begin{array}{l}\text { written exam }+ \\
\text { interview }\end{array}$ \\
\hline & $\begin{array}{l}\text { Ergonomics } \\
\text { practitioner } \\
\text { (option 3) }\end{array}$ & Any college degree & $\geq 10$ yrs job practice & $\begin{array}{l}3 \text { full-fledged } \\
\text { ergonomics } \\
\text { practices }\end{array}$ \\
\hline \multirow[t]{3}{*}{$\begin{array}{l}\text { New } \\
\text { Zealand }\end{array}$} & $\begin{array}{l}\text { Associate } \\
\text { New Zealand } \\
\text { Ergonomist }\end{array}$ & \multirow{2}{*}{$\begin{array}{l}\geq 3 \text { years academic formation in any } \\
\text { field, at least } 1 \text { year in ergonomics } \\
\text { (corresponds to } 500 \text { to } 700 \mathrm{hrs} \\
\text { ergonomics education) }\end{array}$} & $\begin{array}{l}\geq 1 \text { year of supervised } \\
\text { training }\end{array}$ & \\
\hline & $\begin{array}{l}\text { Certified } \\
\text { New Zealand } \\
\text { Ergonomist } \\
\text { (Route A) }\end{array}$ & & $\begin{array}{l}\geq 1 \text { year of supervised } \\
\text { training }+2 \text { years of } \\
\text { professional practice } \\
\text { experience }\end{array}$ & $\begin{array}{l}\geq 1 \text { year of } \\
\text { experience have to } \\
\text { be gained in } \\
\text { New Zealand }\end{array}$ \\
\hline & $\begin{array}{l}\text { Certified } \\
\text { New Zealand } \\
\text { Ergonomist } \\
\text { (Route B) }\end{array}$ & Master degree in any field & $\begin{array}{l}\text { Peer-reviewed } \\
\text { publications or } \\
\text { equivalent }+\geq 6 \text { years } \\
\text { experience (post masters } \\
\text { degree) }\end{array}$ & $\begin{array}{l}\geq 2 \text { years of } \\
\text { experience have to } \\
\text { be gained in New } \\
\text { Zealand }\end{array}$ \\
\hline $\begin{array}{l}\text { South } \\
\text { Africa } \\
\text { (previous } \\
\text { draft) }\end{array}$ & $\begin{array}{l}\text { Certified } \\
\text { member of } \\
\text { ESSA }\end{array}$ & $\begin{array}{l}\text { MSc in Ergonomics or a closely } \\
\text { related field ( } \geq 5 \text { yrs) } \\
\text { OR } \\
\text { BSc in Ergonomics or similar ( } \geq 3 \text { yrs) } \\
+ \text { a course in Ergonomics }\end{array}$ & $\begin{array}{l}\mathrm{CV} \text { with } \geq 5 \text { pieces of } \\
\text { written work (e.g. } \\
\text { ergonomics projects } \\
\text { report, research report) }\end{array}$ & $\begin{array}{l}\text { written exam }+ \\
\text { interview }\end{array}$ \\
\hline
\end{tabular}




\begin{tabular}{|l|l|l|l|l|}
\hline Country & Designation & Theory /Education & Practice & Further requirem. \\
\hline & Ergonomics & $\begin{array}{l}\text { Matric + qualification in an allied } \\
\text { field }\end{array}$ & $\geq 2$ yrs of relevant & written exam + \\
\hline
\end{tabular}

Source : ESSA Professional Affairs Board (2014)

\subsection{Challenges in developing education model suites various level of people's education background and experience in ergonomics}

In addition to establishing the minimum educational requirements, there are also concerns of excluding the senior practicing ergonomists who may not have the necessary tertiary qualifications in ergonomics. In Malaysia for example, the concept of ergonomics in the workplace are primarily introduced by safety and health officers in companies. According to the Malaysian $\mathrm{OSH}$ Act 1994, companies are required to hire at least one SHO in their company to lead the OSH activities in the company. Among the common hazards that are encountered would be ergonomic hazards. Usually the first person in the company to detect the problem would be the SHOs, and SHOs would normally perform the ergonomic evaluations in the workplace and propose improvements to the management. It is by this nature that SHOs should also be professional ergonomists, but not all of them have tertiary level education. A debate is still ongoing in our committee concerning the minimum acceptable requirement for educational level. However, the committee in accordance to maintain the high standard of certification will referred the amount of experience suggested by countries that had established country certification.

\subsection{Establishing the route of certification which suites Malaysia context due to diversity of experience, exposure to ergonomics intervention and other programs}

Establishing a single route will be challenging and will exclude certain group of safety and health personnel. Although standardization of a single route into recognition as CPE, early stage of streamlining those with differences in experience is needed. As most of OSH personnel and academician had wide variation of experience including day to day handling of ergonomics issues, case studies, compensation in MSD cases, research project and different type of intervention programs, these group experience and knowledge is important to be included within certification.

\subsection{Coordination between Certified Professional Ergonomist with local competency}

The major hurdle after the official formation of CPE is to ensure the modules as a certified professional ergonomist is on par and above the future requirement of ergonomics assessor that fall under the jurisdictions and legal requirements of OSH Act. The society need to have further discussion with DOSH to ensure that principles and criteria that had been set by the government in appointing ergonomics assessor are complied. The major issue within the legal requirement of the Malaysian government is that, the professional ergonomist certification scheme developed in Malaysia must only be opened for Malaysians, due to the fact that the scheme is originally developed to cater for Malaysian workplaces. Other workplaces in different countries may have different legal requirements plus social and cultural values that may not be compatible with the Malaysian professional ergonomist certification scheme.

Once this hurdle is overcome, the issue of gazetting the Malaysian CPE as equivalent to ergonomics assessor within the legislation. The modules offered should be verified and accredited by a conjoint board comprising of HFEM main CPE board members, representative from Division of Industrial Hygiene from DOSH, representative for examination committee of NIOSH and representatives of Ergonomics Division from NIOSH.

By having a coordinated conjoint board will ensure that the Malaysian CPE will be accepted as equivalent to the future Malaysian Ergonomics assessor.

\subsection{Government and industrial buy in on the need of CPE}

The marketability and the need of CPE would be purely academic without the support and acknowledgement from the government and industries. Without the endorsements from DOSH, the industries will not make use the importance of having a CPE in conducting ergonomics risk assessment in their workplace. Industries are more willing to ensure that their workplace is vetted by assessor that fulfill the requirement by DOSH rather than spending any amount of allocation in 
their yearly safety and health road map in hiring a non-endorsed CPE.

\subsection{Operational challenges in setting up CPE Framework}

One of the biggest challenges is getting the overall framework in the process for certification. A full dedicated team comprise of a combination of renowned certified professional ergonomist, ergonomists from universities, OSH practitioners with ergonomics backgrounds, industrial hygienist, industrial engineers, ergonomists from the government especially from DOSH and NIOSH in order to set the framework and the operational details in order to comply with the requirements by IEA and by the government. Operational challenges to be considered including:

1) Screening process to assess the suitability of applicant

2) Checklist for the ergonomics competency standards for applicants

3) Examination process flow

4) Mechanisms to ensure the confidentiality

5) Methods to test the reliability of the assessment process

6) Terms of Reference and Duties for certification board member

This challenge need to be overcome with a dedicated team in organizing a valid framework that is fool proof and had been tested with continuous improvement in order to ensure the smoothness of the certification process.

\section{Conclusion}

Although there are many issues and challenges for a developing country such as Malaysia in developing its own CPE, the need for the establishment of a national CPE is there. By having its own certification system for ergonomics, Malaysia will be the first country in Southeast Asia that recognizes the importance of ergonomics for the betterment of the nation. Other Southeast Asian nations may follow Malaysia as an example for their own certification scheme.

\section{REFERENCES}

ESSA Professional Affairs Board (2014). Professional Ergonomist Certification by the Ergonomics Society South Africa. Retrieved from https://www.ru.ac.za.

Factories and Machineries Act, Malaysian Statutes (1967).
Occupational Safety and Health Act, Malaysian Statutes (1994) 